\title{
The Partnership of Tourism Stakeholders in Increasing Tourism Competitiveness in Bantul District
}

\author{
$1^{\text {st }}$ Oktiva Anggraini ${ }^{1}$ \\ \{oktivabiyan@yahoo.co.id ${ }^{1}$ \} \\ Faculty of Social Political University of Widya Mataram Ndalem Mangkubumen KT III/237 \\ Yogyakarta $^{1}$
}

\begin{abstract}
This study aims to examine the manifestation of stakeholders' partnership in empowering community and the stages of actuating stakeholder ecotourism partnership in Dlingo district of Bantul regency. The study applied qualitative descriptive research design, focusing on primary data collected through structured interviews, questionnaires and direct observation in addition to secondary data. The research results demonstrate that tourism stakeholder partnership is a collaboration of government officials, universities, and CSR The pioneering collaboration has given birth to various tourism management trainings and art exhibitions. The study reveals that adequate and applicable planning is needed to develop tourist objects and attractions. The slow implementation of various policies concerning tourist area development is inseparable from the dearth of authority possessed by RPH and Dishutbun over forest management which is a national asset, resulting in procedures that seem convoluted. The research results also recommend the improvement of partnership involving various parties, especially in increasing the number and types of tourism and culinary trainings. The pattern of communication and coordination between pertinent institutions and tourism stakeholders should be intensified in solving problems in the field. Universities can contribute to scientific contributions in bridging the difficulties of the local village government in managing tourism in preserved forests.
\end{abstract}

Keywords: Partnership, Tourism Stakeholders, Ecotourism.

\section{Introduction}

Sustainable tourism is one of the most effective ways to provide economic opportunities and employment for local people while protecting natural resources in the world, one of which is ecotourism. It has been growing at over 20 percent per year, two to three times faster than the tourism industry as a whole. Even important to raise awareness of the contribution of sustainable tourism to development among private and public sector decision makers was the fact that the $70^{\text {th }}$ UN General Assembly was stipulated in 2017 as the International Year of Sustainable Tourism for Development. This effort is simultaneously aimed to mobilize all stakeholders in the world to work together in making tourism a catalyst for positive change.

The five aspects targeted from ecotourism development include (1) inclusive and sustainable economic growth (2) social inclusiveness, employment and poverty reduction (3) resource efficiency, environmental protection and climate change (4) cultural values, diversity and cultural heritage (5) mutual understanding, peace and security (UNWTO, 2016) (CIFOR, 2017). 
In line with the rapid development of the global tourism industry, the development of the Indonesian tourism industry has also experienced remarkable developments. Tourism contributes to $10 \%$ of national GDP and the highest in Asia, contributing fourth place to foreign exchange at $9.3 \%$ and contributing labor to 9.8 million jobs (UNWTO 2016). The government determination to develop tourist villages as a generator driving the village economy can be seen from the revolving fund of Rp. 123,25 billion through the Ministry of Tourism and Creative Economy. Furthermore, economic activities not only move in urban areas, but also take place in rural areas. Movement and economic growth in tourist areas will create jobs, which can reduce the movement of labor to the city while reducing poverty in rural areas (Putra and Pitana, 2010).

Considering the development target of tourism villages involves tangible and intangible elements so that inevitably the involvement of local communities is absolutely necessary. A number of studies show that rural tourism development cannot be separated from local economic development (Anggraini, 2016; Zhong, 2017; Nengah, 2006). Conflicts of interest in ecotourism development tend to emerge along with local economic development. Partnership (collaboration) in turn becomes a method to accommodate various interests around preserved areas (Suporahardjo, 2005). This method is a form of conflict resolution that accommodates high cooperative and assertive attitudes. Collaboration becomes conflict resolution which results in a "win-win" situation (Tadjudin, 2009). The collaborative approach includes three main stages namely, (1) preparing partnership, (2) developing agreements, and (3) implementing and reviewing agreements.

The level of community involvement is very diverse as manifested in 1) leasing land for tourist attractions along with land use supervision, 2) working as full or part time employees; 3) providing services such as catering, transportation, shops etc. or 4) establishing joint venture management of tourist areas between local government, private sector and the community as pointed out by Anggraini (2016) and Nengah (2006). The empowerment in tourist villages is inextricably related to the role of community leaders who are able to convince citizens, that is concerned with ensuring changes that must be jointly carried out to organize infrastructure that meets the qualifications and requests of visitors. The novelty of this research focuses on the role of cooperatives in managing local wisdom-based ecotourism.

In the midst of competition for tourist destinations in Indonesia, one of the destinations developed by the government of the Special Region of Yogyakarta is tourist villages in Dlingo district, Bantul regency. This area has preserved forest area with an area of 1,041.20 ha under the auspices of RPH (Forest Guiding Resort) of Mangunan. This area was initially managed as a production forest producing pine resin for the basic ingredients of turpentine and Gondorukem.

In the management of tourist villages, a number of problems come under the spotlight, namely the lack of infrastructure for tourist destinations, the lack of organized and applicable tourist destination planning models. Departing from this issue, the study is projected to examine the form of stakeholder partnership in empowering the community and the stages of implementing partnership in the research site. 


\section{Research Method}

This study applied a descriptive qualitative design. Primary data collection included structured interviews, questionnaires and direct observation. The key informants were determined by purposive sampling, namely Chairman of RPH (Forest Management Resort), Forest Service of Special Region of Yogyakarta, chairman, members and Notowono cooperatives, management of farmer groups, community leaders, residents of research sites; officials from the Bantul Regency Education department, and Culture and Tourism Office. Field survey was done by distributing questionnaires to record the process of tourism village empowerment, response of visitors to tourist destinations and citizen involvement in the management of tourist villages. Secondary data collection was investigated through analyzing documents to analyze community empowerment regulations at the research site and map potential research areas. To ensure data validity, data source triangulation was done by collecting similar data from several different data sources. Data sources were developed and stored so that at any time they can be traced back when verification was deemed necessary.

\section{Result}

\section{Description of the Research Site}

Administratively, natural pine forests are located in Terong village, Dlingo district, Bantul regency, in Special Region of Yogyakarta. Nature tourism Pine forests are located at an altitude of 325-350 meters above sea level with an average temperature ranging from $24^{\circ} \mathrm{C}$ $27^{\circ} \mathrm{C}$.

With the spirit of Sapta Pesona (safe, orderly, clean, cool, beautiful, friendly and memorable), the natural tourism area continues to improve. To support the function of the forest as a natural tourist attraction and culture, a number of facilities were underway, which included parking lots, levy counters, toilets, prayer rooms, restaurants, gazebos, viewing posts, theater venues and a number of forest-themed photo spots.

The management of tourist destinations in this tourist attraction was under the control of Notowono Cooperative, namely Mount Pengger, Becici Peak, Dahromo Valley, Lintang Sewu, Pinus Asri, Pinussari, Seribu Batu, Panguk hill, and Mojo hill.

\section{Partnership Map of Tourism Stakeholders in Tourism Village Development}

The identification of stakeholders and their interests was done by field observations and interviews with purposive sampling. Stakeholder classification was done by interpreting the matrix of stakeholders' interests and influence on the development of ecotourism at the research site. The results of stakeholder identification indicated that stakeholders came from government agencies, communities, universities and the private sector. Stakeholders from central government elements became important party in ecotourism management. The role followed the protection of natural resources in the forest area, community empowerment, 
provision of ecotourism services, provision of data and information on ecotourism. Stakeholders from local and district government elements played a role in empowering local communities and informants to gain information on ecotourism at the research sites.

Stakeholders from the community elements consisted of community groups in Dlingo district, the lives of the surrounding community depended on nature and cultural richness. Stakeholders from the community elements played a role as tourism service providers, tour guides, cooks, parking service providers and homestay owners. Stakeholders from nongovernmental organizations (NGOs) namely the World Wildlife Fund (WWF) are non-profit institutions in the field of natural conservation. Stakeholders from tertiary institutions in Yogyakarta were responsible for conducting environmental education and increasing people's insight and understanding of the preservation of forest ecosystems. Stakeholders from the private sector include travel tour entrepreneurs, transportation entrepreneurs, and event organizers. This private group had a role in providing employment opportunities for local people and the provision of tourism services (restaurant accommodation, food industry and other facilities) required by visitors.

\section{The Stages of Ecotourism Stakeholder Partnership}

The stage of ecotourism stakeholder partnership began with preparation, making commitments between community leaders and the government, which is pertinent to Grand Design Wana Budaya Wisata Mataram by the Forestry and DIY Plantation Service with CV Enkorp. It was agreed that the concept developed was a two-way concept namely forest development and forest stakeholders. The concept of forest development was management in the forest area itself. The development of forest stakeholders was more directed at empowering communities around the forest by developing the Kaki Langit village or Dewi Kalang. Dewi Kalang was the name chosen as the branding for the development of tourist villages around the preserved forest of Dlingo district.

In contrast to the ecotourism management in other areas that relied on groups taking care of tourism, the driving center in Dlingo district was cooperatives. Notowono cooperative was a legal entity formed by local youth leaders named Purwoharsono, consisting of Pesanggem farmers (forest cultivators) and surrounding communities. Based on local wisdom shared among local communities, cooperative management was considered to better facilitate communication clogging and chaotic interests in the forest and its protection.

The initial challenge of managing tourism villages was to change the mindset of village communities from the livelihoods of farmers to service managers, especially natural environmental services. Mr. Purwoharsono in tandem with Notowono Cooperative applied a Sapta-based tourism standard of charm that was quite strict especially in terms of cleanliness. Services for visitors, for example in product prices, had received close supervision because they included tourism images from Mangunan preserved forests, in particular, and Special Region of Yogyakarta, in general.

Since its establishment, it had 243 people. Mangunan RPH had an area of 573.7 ha, with an area of utilization block, 411 ha. The Notowono Cooperative proposed an area of management of natural tourism covering an area of 41 ha or $10 \%$ of the utilization block but 
only 29.4 ha was approved by the KPH (a unit of forest management). The agreed area stretched from the northern part of the forest area to the south from Pengger, Becici, Lintang Sewu, Pinus Sari, Seribu Batu, Mojo and Panguk. The area includes three villages.

Strengthening rural tourism institutions was very dependent on enforcement of the rules. Therefore, rules are agreed upon by members of the Cooperative group. Rules included agreements and commitments about sanctions given if the rules were violated. Sanctions covered business activities, such as stalls, which was given when the manager or operator received three complaints from visitors. In the process of assisting the village community, Ki Hajar Dewantoro's principle, Ing Ngarso sung tulodho was in place, which meant that the companion had to provide a direct example in carrying out the activities; Ing Madyo mangun karso, the assistant had to work in the midst of the community; Tut wuri handayani meaning that the facilitator had to be able to encourage and encourage so that activities can continue.

Notowono cooperative coordinated group units as natural tourism operators for each place. The division of these units was based on farmer groups that had specifications in the concept of tourism they develop. For example, in the Pinus Pengger destination, the concept he developed was in the form of a unique building, Hand Praying, City Gate, and a selfie concept framed with a panoramic view of the city. In Becici, the concept of sunrise and sunset panorama was developed.

Becici Asri Peak area covered an area of 4.4 ha, including the Mount Cilik, Muntuk village, and Dlingo district, while Pinus Pengger covered the Terong block with the Sendangsari, Terong, and Dlingo Bantul areas covering 3.8 hectares. Compared to the extent, the coverage area of the management of Becici Park was responsible for managing land greater than Pinus Pengger. Of the operators' management areas, the Pinusasri area was the largest, 9.3 ha with the location of the Mangunan village, Mangunan village, Dlingo Bantul district.

Based on the above explanation, it appeared that the mapping of the abattoir potential, Notowono Cooperative and Dishutbun was based on local wisdom. The initial stage of the stakeholder partnership was marked by awareness of the community about the potential that had been running for a long time. The limitations of education and the skills of the residents had resulted in the rich natural resources in the region not being optimally presented as attractive tourism objects. In the arts sector, for example, it was necessary to design appropriate arts packages to make them attractive part of tourism potential. Traditional arts groups needed more intensive coaching.

The next thing to ponder was the stage of developing a partnership agreement. The implementation of stakeholder partnership in research site was based on a number of regulations. From the juridical side, Special Region of Yogyakarta's Governor Regulation no. 5 of 2018 concerning Collaboration on Utilization of Production Forests and Preserved Forests as well as Collaboration and Licensing for Utilization of Forest Parks was found sufficient to protect parties including Pokdarwis/Forest Operator Operators. As stipulated in the Governor's regulation, the object of cooperation included:

1) Utilization of Production Forests.

2) Activities for Utilizing Production Forests

3) Utilization of the Area through various businesses 
4) Use of Environmental Services through business activities:

5) Utilization of Timber Forest Products

6) Utilization of Non-Timber Forest Products

7) Collection of Non-Timber Forest Products

\section{The Cooperation Object in the Utilization of Preserved Forests}

The Governor Regulation reinforces the previous cooperation agreement on the utilization of Protection Forest in Mangunan RPH, BDH Kulon Progo, KPH Hall between the Forestry and Plantation Office of Special Region of Yogyakarta with Notowono Cooperative number $525 / 00909 /$ number $003 / \mathrm{NW} / \mathrm{MNG} / \mathrm{I} / 2 / 017$ signed on 31 January 2017. The core of this cooperation was the Utilization of Preserved Forests in the Mangunan Forest Management Resort (RPH), Part of the Forest Area (BDH) Kulon Progo Bantul, the mutually beneficial Yogyakarta Forest Management Unit (Balai KPH). The scope of cooperation included utilization of Protection Forests covering business areas and types of businesses.

Cooperation between the parties was carried out by keeping the status and function of the forest intact. The implementation of forest utilization activities involved the local community. Community groups as referred to in paragraph (3) were community groups belonging to Pinussari, Becici Asri, Bukit Lintang Sewu, Gunung Pengger, Seribu Batu, Mount Mojo and Bukit Panguk groups. With the wide area of the object of business cooperation, the utilization of natural tourism environmental services covering an area of 29.4 ha consisted of:

a. Pinussari (Sudimoro II and III): $9.3 \mathrm{Ha}$

b. Becici Peak (Sudimoro I): $4.4 \mathrm{Ha}$

c. Bukit Lintang Sewu (Sudimoro II): $4.7 \mathrm{Ha}$

d. Gunung Pengger (Terong Block): $3.8 \mathrm{Ha}$

e. Seribu Batu (Sudimoro III): $2.2 \mathrm{Ha}$

f. Bukit Mojo (Gumelem): $1.7 \mathrm{Ha}$

g. Bukit Panguk (Kediwung): $3.3 \mathrm{Ha}$

In the agreement, it was arranged so that the construction of the form of natural tourism facilities in the form of semi-permanent buildings or in accordance with planning documents and their forms adapted to the local cultural architecture. Natural tourism facilities can be facilitated by the government, Noto Wono cooperatives and other non-binding parties. The cost of maintaining natural tourism facilities can be sourced from the government, the Noto Wono Cooperative and other non-binding parties. Cooperation was carried out in a profitsharing consent according to the agreement of both parties. The share stated $25 \%$ for the Regional government and $75 \%$ for the Noto Wono Cooperative. The Cooperative Noto Wono was able to collaborate with other parties with KPH permits. Based on the description above, it appeared that the cooperation between tourism stakeholders was preserved by a number of strict regulations, seemingly inflexible. The cooperatives and community members found it hard to cooperate, except through selection from the Dishutbun and KPH parties. Both of these agencies had strong reasons to remember that every person or party who gained profits on state land was under the supervision of the two agencies. 
The slow implementation of tourism area development policies was driven by the lack of authority possessed by RPH and Dishutbun, forest management which was a national asset, resulting in procedures that seemed convoluted. Many parties were involved in tourism development such as the Tourism Office and Bantul regency government. The high sectoral ego resulted in a pattern of coordination and cooperation that was not as simple as expected. This was a challenge for tourism stakeholders because the needs of each tourist destination and the demands of visitors varied.

The final step of the partnership was the review stage. At this stage, the activity of assessing partnership achievements, accommodating feedback and improving follow-up actions were put under analysis. Collaboration on environmental services between Notowono Cooperative and KPH Mangunan officially was commenced on January 31, 2017. Based on the agreement, there were thirteen natural environment services that can be developed as sources of income in the management of natural tourism. But at the moment, only two items have resulted in entrance fee to the location and parking fees.

With an average visitor of 200 people per day, the Cooperative was able to earn revenue from only two items. The total income was approximately 5.15 billion in the last eight months. According to the agreement, $25 \%$ of the revenue, which was 1.2 billion, had been deposited into the treasury of the DIY province.

Based on data from the Notowono Cooperative (2017), the largest number of visitors from nine destination regions in Dlingo district reached 800,642,000. Next position was Becici Peak Park 427,885,000. The average number of visitors increased during school holidays, like December. Becici Park peak, which in November 2017 reached 29.038, increased in December to 62.218. Becici Peak in November numbered 34.641, December increased to 75.963. Pinus Asri, which in November was marked with 5.163 visitors, reached 15,545 people in December. Visitors to Pinus Sari from the nine most regions, in November 42,992, while in December it increased to 108,248. Seribu Batu in November gained 24.504 visitors and 64.950 people in December. In Bukit Panguk, there were 3.665 visitors in November, reaching to 9.489 people in December.

The high interest of tourists in preserved forest tourism areas attracted investors to invest. With the stronghold of village regulation (Perdes) and local wisdom, the Cooperative administrators reacted with caution. The investor's interest in establishing a hotel must be prevented and directed to the development of a home stay so that the community was more empowered. The community was still able to receive benefits directly. Thus, the village regulation was to ensure that the existence of this investment not counter-productive to the community welfare. The hope was that in the future, people will not become helpers in their own homes (interview with Purwoharsono, March, 2018).

The resort construction was a consequence of the development of Mangunan tourism. Currently there were 25 homestays built in Mangunan. The management was targeting 105 homestays in the Mangunan area. The benchmark was that half of the heads of households (HHs) had a home stay. Thus, residents were expected to enjoy the development of tourist villages.

A number of residents, as found in the interview, revealed that economic changes were quite satisfactory after the flow of tourists into the location of Pinus Pengger and Becici Park. 
"In the past, many unemployed youth who did not have jobs after farming can now manage parking or move in other tourism services", interview with Jumar Head of Pinus Pengger Operator (February 2018). Many left their work as farmers, switching to managing tourism services because they were considered more profitable. This was in accordance with the expectations of the development of the tourism village itself, as a generator of regional development and reducing unemployment because it was considered capable of creating jobs. Each operator area in turn was developed by the local village community, to develop the local area in order to help widows, the poor and orphans.

Cooperative management agreement with the village was concerned with the strict rules for hotel investment in tourist areas. The ownership of all homestays was still in the hand of Mangunan residents. When there were investors having resorts or homestays, the village was liberated to intervene in the management. Observations showed that village tourism facilities and facilities were still minimal in n7umber. In the provision of mosques, for example, the manager was trying to coordinate with the village to establish it. However, regulations do not allow the construction of permanent mosques to be erected in the middle of the forest. Construction of toilets is felt to be increasingly urgent as the number of tourists increases sharply. The quantity of toilet is not sufficient in quantity. The actual construction was longer than desired, considering that the budgeting authority depended on the central government. The management of preserved forests as a national asset was dependent on the budget allocation of the central government. Based on existing regulations, the supervision of forest use was carried out by the Forestry Utilization Unit by working with communities or residents around the forest. Thus, tourism activities and their use would not damage natural resources and so that future generations could benefit from them or, in other words, these resources would have an acceptable impact.

\section{Conclusion}

The partnership of tourism stakeholders established at the research site is a collaboration involving government officials, Notowono Cooperatives, universities and CSR. The collaboration initiative has given birth to various tourism management trainings and art exhibitions. The rapid increase in the number of visitors and the increasing demand for services and tourism services require creativity, innovation, cooperation, promotion, good coordination and marketing. The slow implementation of various policies in tourism area development is inseparable from the lack of authority owned by RPH and Dishutbun over forest management as a national asset. As a corollary, this has resulted in convoluted procedures.

\section{Suggestion}

To actualize a comfortable, beautiful and memorable tourist destination for visitors, partnership with various parties should be improved, especially in increasing the number and types of tourism and culinary training. The pattern of communication and coordination 
between pertinent institutions and tourism stakeholders should be intensified in solving problems in the field. Universities can contribute to scientific contributions in bridging the difficulties of the local village government in managing tourism, particularly preserved forests.

\section{Reference}

[1]. Anggraini, Oktiva, 2016. Penguatan Lembaga Masyarakat Pesisir Perspektif Gender http://repository.widyamataram.ac.id/uploads/pdfs/2016_-

JURNAL_POPULIKA_VOL.V_NO_.2_JANUARI_2016_.pdf

[2]. Nengah, Subadra I. dan Nyoman Mastiana Nadra, Dampak Ekonomi, Sosial Budaya dan Lingkungan Pengembangan Desa Wisata di Jatiluwih Tabanan, Jurnal Manajemen ariwisata, Juni 2006, vol. 5, nomor 1 .

[3]. Pitana, I Gede. \& Surya Diarta, I Ketut, 2010, Pengantar Ilmu Pariwisata. Yogyakarta: ANDI.

[4]. Suporahardjo, 2005, Manajemen Kolaborasi: Memahami Pluralisme Membangun Konsensus/ Penerjemah Mokhsen Assagaf, Dudik Trajudi [et al]. Pustaka Latin: Bogor.

[5]. Tadjudin, Djuhendi, 2009, Manajemen Kolaborasi. Pustaka Latin: Bogor.

[6]. Zhong Linsheng, Liu Limin, Ecotourism Development in China: Achievements, Problems and Strategies, J. Resour. Ecol. 2017 8(5) 441-448 DOI: 10.5814/j.issn.1674-764x.2017.05.001

[7]. www.jorae.cn.

[8]. CIFOR, 2017, Membangun Bentang alam Berkelanjutan, mengurai dan memperkuat Kebijakan, Bogor, Indonesia: Pusat Penelitian Kehutanan Internasional (CIFOR)

[9]. UNWTO Annual Report 2016, Published by the World Tourism Organization (UNWTO), Madrid, Sp. 